\title{
Influence of permanent and variable factors on the number and area of forest fires in the Amur region
}

\author{
Olga Dyadchenko ${ }^{1,}$, Natalia Timchenko ${ }^{1}$, and Alexandr Baranov ${ }^{1}$ \\ ${ }^{1}$ Far Eastern State Agrarian University, Blagoveshchensk, 675000 Amur Region, Russia
}

\begin{abstract}
The article presents a study of the connection between the number and area of forest fires on the territory of the Amur Region from the area of forestries. the length of mineralized belts in each forestry. the natural class of fire hazard. and the class of fire hazard by weather conditions. A stable relationship between the number of forest fires and the fire hazard class by weather conditions has been revealed. This dependence is presented in the form of a model that makes it possible to predict the number of forest fires both on the territory of the forest fund of the entire Amur Region. and for individual forestries.
\end{abstract}

\section{Introductory part}

The Amur Region. which is part of the Far Eastern Federal District of the Russian Federation. is especially prone to forest fires. Every year. a large number of fires of various types and intensities occur in the region. Forest fires are a natural factor. but frequent and especially forest catastrophic fires cause hard-to-replace damage both to flora and fauna. and the regional economy. as well as public health [8. 10]. The occurrence and spread of forest fires mainly depend on meteorological conditions. such as temperature and humidity. An enormous part is played by the amount of precipitation and the duration without rainy periods [5.9. 11. 12].

Many studies have already established the link between forest fires and weather conditions. A number of scientists have highlighted the importance of the precipitation regime (or dry periods) in fire activity in southwestern China [7]. D.R. Anto found that relative humidity shows a higher correlation with the monthly number of fires in Germany compared to temperature or rainfall [4].

Of particular scientific interest is the relationship between the classes of weather fire hazard and the number of forest fires occurring in the territory [4. 13. 15. 17]. Temperature. humidity. wind speed and rainfall determine the number and extent of forest fires. Also. knowing the class of weather fire hazard. it is possible to predict the degree of intensity and speed of spread of a forest fire [16]. Various forest fire hazard rating systems have been developed to prevent and manage forest fires at the country level [14].

\footnotetext{
* Corresponding author: diadchenko-1981@mail.ru
} 
In the vast expanses of Russian forests it is impossible to fight fires in all forest growing zones. the country's economy will not be able to withstand such costs. This is common in many countries. as forest fires in Algeria destroy on average over 32.000 hectares per year. despite the adopted prevention and control plan. They are the most damaging factor in forest degradation and have a major impact on the environment and local economy. Conventional fire prevention and control methods are time consuming and not always reliable due to the complexity and diversity of forest ecosystems [6].

This work is aimed at studying the relationship between the weather fire hazard and the area of forest fires. as well as the volume of preventive forestry activities (creation of fireprevention mineralized belts) in the forestries of the Amur Region.

The results are expected to justify an increase in preventive fire measures and a decrease in the occurrence of large forest fires in areas with a high weather fire hazard class.

\section{Materials and methods}

The data on fires were obtained from the state autonomous institution of the Amur Region "Air Base" (hereinafter referred to as the Air Base) and contains information on the number of forest fires in the forestries of the Amur Region. their area for the period 2017-2019.

\subsection{Data analysis method}

This analysis aims to establish the relationship between the number and area of forest fires. depending on the constant and variable factors that influence the occurrence and spread of fire.

The factors taken into account when determining the dependences of the area and the number of forest fires are divided into constant and variable.

Constant factors:

- the area of forestries and its distribution according to fire hazard classes according to natural conditions;

- the length of the mineralized belts in forestries;

Variable factors:

- class of fire hazard according to weather conditions.

The main method for determining the dependences of the number and area of forest fires on influencing factors is the method of constructing a trend line and determining the value of the approximation reliability.

\section{Results}

For the emergence and spread of a fire. three conditions must be observed: the presence of combustion products and oxygen. as well as a temperature sufficient for the emergence and maintenance of fire. Elimination of one of the factors contributes to the elimination of the fire. This rule also applies to natural fires. which occur mainly due to the fault of a person with uncontrolled and irresponsible handling of fire.

At present. in the prevention of the occurrence and spread of wildfires. the method of excluding combustible materials from the zone of possible occurrence or spread of fire is used. These methods include carrying out preventive annealing of dry vegetation and the system of mineralized belts.

Since the fall of 2019. the Ministry of Forestry and Fire Safety of the Amur Region (hereinafter referred to as the Ministry) has refused to carry out preventive annealing of dry vegetation on the territory of the state forest fund of the region in favor of arranging and 
maintaining fire-fighting forest infrastructure. including the creation and renewal of mineralized belts.

The state forestry fund of the region is organized by the State Agrarian Administration of the Amur Region "Leskhozes" (hereinafter - leshozes) and forest users. In the region there are 11 forestry enterprises that carry out fire-prevention arrangement of forests within the framework of the fulfillment of the state assignment. and forest users in the areas used in the framework of the fulfillment of contractual obligations and the requirements of forest development projects.

Control over the quality of implementation of fire-prevention measures is carried out by state forest inspectors of the GKU of the Amur region "Lesnichestvos" (hereinafter Lesnichestvos). In total. there are 13 forestries in the region. each of which has a certain territory of the state forest fund.

From our point of view. the location of the fire-prevention infrastructure. including mineralized zones. should be determined taking into account the class of natural fire hazard (Table 1). Forest users are limited in choosing the location of mineralized belts by the territory of the site being in use. therefore. the main role in ensuring the most rational location of mineralized belts remains with the executive authority. which. in accordance with the Forest Code of the Russian Federation. has been delegated powers in the field of forest management. Such an organ in the Amur Region is the ministry. which in turn assigns part of the delegated powers to the subordinate institutions of the forestry. forestry enterprises and the Air Base.

Table 1. Class of natural fire hazard of the forestries of the Amur region.

\begin{tabular}{|c|c|c|c|c|c|c|c|c|}
\hline \multirow{3}{*}{ Z } & \multirow{3}{*}{ 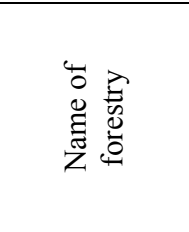 } & \multicolumn{6}{|c|}{ Area. ha } & \multirow{3}{*}{ 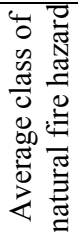 } \\
\hline & & \multirow{2}{*}{$\begin{array}{l}\bar{\pi} \\
\overline{0} \\
\overline{0}\end{array}$} & \multicolumn{5}{|c|}{ By classes of natural fire hazard } & \\
\hline & & & - & $\Xi$ & ヨ & $\geq$ & $>$ & \\
\hline 1. & $\begin{array}{c}\text { Arkharinskoy } \\
\text { e }\end{array}$ & 887469 & 55010 & 242376 & 309551 & 237376 & 43156 & 3.0 \\
\hline 2. & Belogorskoye & 803600 & 11455 & 8218 & 726844 & 57083 & 0 & 3.0 \\
\hline 3. & $\begin{array}{l}\text { Blagoveshche } \\
\text { nskoye }\end{array}$ & 73542 & 73542 & 0 & 0 & 0 & 0 & 1.0 \\
\hline 4. & Bureyskoye & 457262 & 45005 & 67937 & 332105 & 11459 & 756 & 2.6 \\
\hline 5. & Zavitinskoye & 107095 & 31572 & 23019 & 52504 & 0 & 0 & 2.2 \\
\hline 6. & Zeyskoye & 879324 & 312637 & 1354091 & 5745172 & 1214831 & 166509 & 3.0 \\
\hline 7. & $\begin{array}{c}\text { Magdagachins } \\
\text { koye }\end{array}$ & 1308852 & 83487 & 363571 & 827626 & 34168 & 0 & 2.6 \\
\hline 8. & $\begin{array}{c}\text { Mazanovskoy } \\
\text { e }\end{array}$ & 2223589 & 50391 & 128942 & 1655221 & 382497 & 6538 & 3.1 \\
\hline 9. & Norskoye & 4012232 & 486465 & 268290 & 2685034 & 572443 & 0 & 2.9 \\
\hline 10. & $\begin{array}{c}\text { Svobodnensk } \\
\text { oye }\end{array}$ & 349575 & 7560 & 204687 & 58650 & 8556 & 2072 & 2.0 \\
\hline 11. & Tyndinskoye & 7858015 & 1194714 & 2004978 & 4100138 & 526663 & 31522 & 2.7 \\
\hline 12. & Urushinskoye & 2483819 & 489887 & 1307495 & 610048 & 76389 & 0 & 2.0 \\
\hline 13. & $\begin{array}{c}\text { Shimanovsko } \\
\text { ye }\end{array}$ & 1157749 & 186273 & 632075 & 304426 & 34416 & 559 & 2.2 \\
\hline & Total: & 22602123 & 3027998 & 6605679 & 17407319 & 3155881 & 251112 & 2.5 \\
\hline
\end{tabular}

Depending on the age and type of forest growing in a particular area. a natural fire hazard class is assigned. The distribution of natural forest fire hazard classes among forestries is not uniform (Table 1) [1.2]. Determination of natural fire hazard classes is 
carried out on the basis of the order of the Federal Forestry Agency dated 05.07.2011 No. 287 "On approval of the classification of natural fire hazard in forests and the classification of fire hazard in forests. depending on weather conditions" [3].

Forestries annually. within the framework of the fulfillment of the state assignment. are brought up the volume of work on the arrangement and renewal of mineralized belts (Table 2).

Table 2. Distribution of the length of mineralized belts by forestry.

\begin{tabular}{|c|c|c|c|c|c|c|c|c|}
\hline \multirow{2}{*}{$\dot{z}$} & \multirow[t]{2}{*}{ Name of forestry } & \multicolumn{3}{|c|}{$\begin{array}{l}\text { Arrangement of mineralized } \\
\text { belts. } \mathrm{km}\end{array}$} & \multicolumn{3}{|c|}{$\begin{array}{c}\text { Maintenance of } \\
\text { mineralized belts. } \mathrm{km}\end{array}$} & \multirow{2}{*}{$\begin{array}{c}\text { Average } \\
\text { length } \\
\mathrm{km}\end{array}$} \\
\hline & & 2017 & 2018 & 2019 & 2017 & 2018 & 2019 & \\
\hline 1. & Arkharinskoye & 88.4 & 88.4 & 88.4 & 378 & 378 & 378 & 466.40 \\
\hline 2. & Belogorskoye & 190 & 190 & 163.4 & 500 & 500 & 500 & 681.13 \\
\hline 3. & $\begin{array}{c}\text { Blagoveshchenskoy } \\
\text { e }\end{array}$ & 126.4 & 126.4 & 126.4 & 513 & 513 & 513 & 639.40 \\
\hline 4. & Bureyskoye & 138 & 138 & 138 & 189 & 189 & 189 & 327.00 \\
\hline 5. & Zavitinskoe & 160 & 160 & 150 & 296 & 296 & 296 & 452.67 \\
\hline 6. & Zeyskoye & 194.4 & 194.4 & 194.4 & 300 & 300 & 300 & 494.40 \\
\hline 7. & Magdagachinskoye & 206.2 & 206.2 & 206.2 & 205 & 205 & 205 & 411.20 \\
\hline 8. & Mazanovskoye & 265.1 & 265.1 & 265.1 & 305 & 305 & 305 & 570.10 \\
\hline 9. & Norskoye & 165 & 165 & 165 & 189 & 189 & 189 & 354.00 \\
\hline 10. & Svobodnenskoye & 129.6 & 129.6 & 129.6 & 475 & 475 & 475 & 604.60 \\
\hline 11. & Tyndinskoye & 115 & 115 & 115 & 170 & 170 & 170 & 285.00 \\
\hline 12. & Urushinskoye & 0 & 0 & 0 & 0 & 0 & 0 & 0 \\
\hline 13. & Shimanovskoye & 363.4 & 363.4 & 400 & 725 & 725 & 725 & 1100.60 \\
\hline & Total: & $\begin{array}{c}2141 . \\
5\end{array}$ & 2141.5 & 2141.5 & 4245 & 4245 & 4245 & 6386.5 \\
\hline
\end{tabular}

The length of the mineralized belts by forestry in the period from 2017 to 2019 practically did not change. with the exception of three forestries in 2019. The length of the mineralized belts decreased by 26.6 and $10 \mathrm{~km}$ in Belogorskoye and Zavitinskoye forestries. respectively. these volumes were fulfilled in Shimanovskoye forestry. Targets for 2020 are identical to those for 2019.

The territory of the Urushinskoe forestry is not equipped with fire-fighting infrastructure within the framework of the state assignment. The reason is the absence of a forestry enterprise. the nearest one is located in Tynda.

Let us compare the data on the length of the mineralized belts to the territory of the state forest fund of forestries by the classes of natural fire hazard (Table 3 ).

The average length of the mineralized belts per 1 hectare of forest area is $0.3 \mathrm{~m}$. There is no direct dependence of the length of the mineralized belts on the forest area (see Fig. 1). The greatest length of mineralized belts per unit area is observed in the Blagoveshchenskoye. Zavitinskoye. Svobodnenskoye and Shimanovskoye forestries. $8.7 \mathrm{~m}$. $4.2 \mathrm{~m} .1 .7 \mathrm{~m}$ and $1 \mathrm{~m}$. respectively. 
Table 3. Distribution of the length of mineralized belts per unit from the area of forestry.

\begin{tabular}{|l|c|c|c|c|}
\hline No. & Name of forestry & $\begin{array}{c}\text { Average length of } \\
\text { mineralized belts. } \mathrm{m}\end{array}$ & $\begin{array}{c}\text { Total area of } \\
\text { forestry. ha }\end{array}$ & $\begin{array}{c}\text { Length of mineralized belts } \\
\text { per unit area. } \mathrm{m} / \mathrm{ha}\end{array}$ \\
\hline 1. & Arkharinskoye & 466400 & 887469 & 0.5 \\
\hline 2. & Belogorskoye & 681130 & 803600 & 0.8 \\
\hline 3. & Blagoveshchenskoye & 639400 & 73542 & 8.7 \\
\hline 4. & Bureyskoye & 327000 & 457262 & 0.7 \\
\hline 5. & Zavitinskoe & 452670 & 107095 & 4.2 \\
\hline 6. & Zeyskoye & 494400 & 879324 & 0.6 \\
\hline 7. & Magdagachinskoye & 411200 & 1308852 & 0.3 \\
\hline 8. & Mazanovskoye & 570100 & 2223589 & 0.3 \\
\hline 9. & Norskoye & 354000 & 4012232 & 0.1 \\
\hline 10. & Svobodnenskoye & 604600 & 349575 & 1.7 \\
\hline 11. & Tyndinskoye & 285000 & 7858015 & 0.0 \\
\hline 12. & Urushinskoye & 0 & 2483819 & 0.0 \\
\hline 13. & Shimanovskoye & 1100600 & 1157749 & 1.0 \\
\hline \multicolumn{7}{r}{} & Total: & 6386500 & 22602123 & 0.3 \\
\hline
\end{tabular}

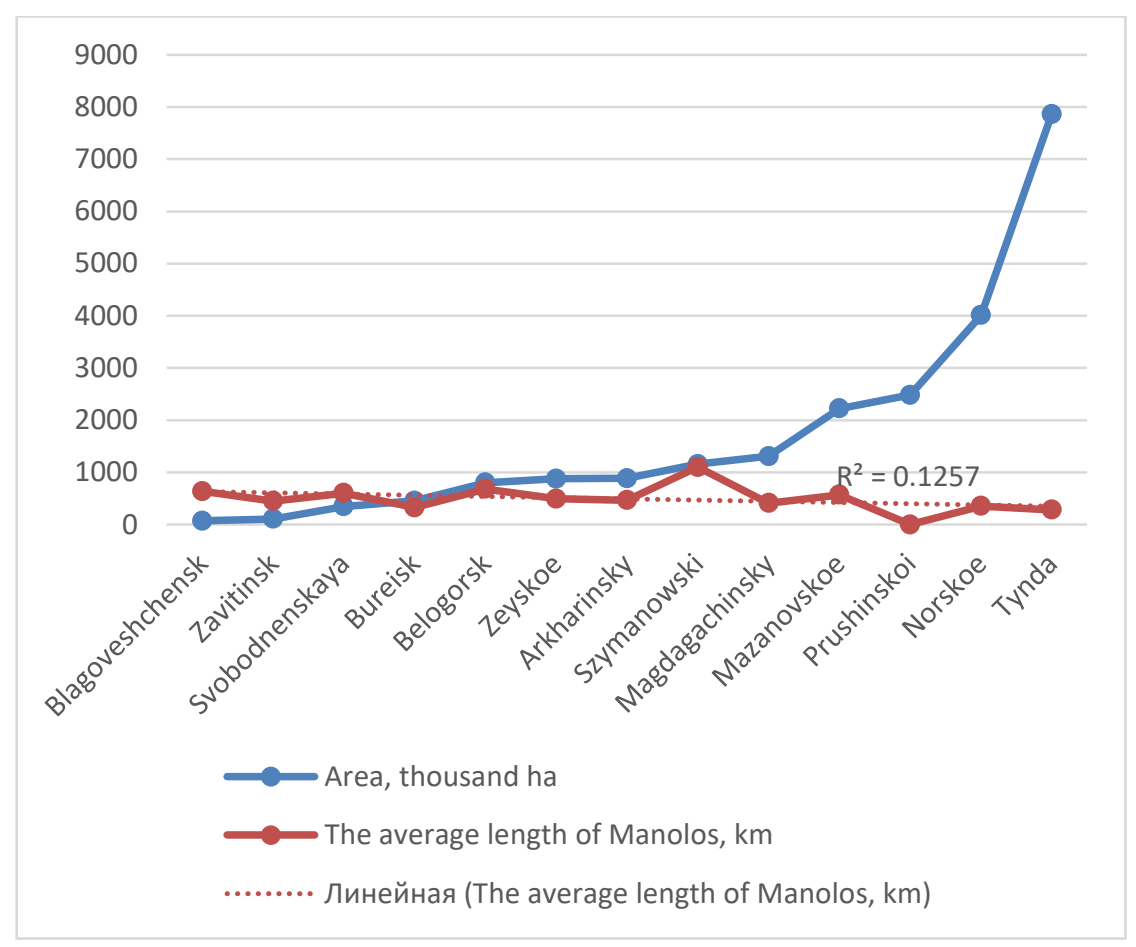

Fig. 1. Dependence of the length of the mineralized belts on the area of the forestry.

With the approximation confidence factor equal to $\mathrm{R} 2=0.123$. it is impossible to speak of a high level of accuracy of the model describing the dependence of the length of the structure of mineralized belts on the area of the forestry. In other words. the length of the mineralized belts does not depend on the area of the forestry in which they are made.

It is possible that the decision on the distribution of the length of the mineralized belts across forest ranges was made regardless of the number of forests of a particular fire hazard class. but on the basis of the average number of forest fires and their area in each of the forestry (Table 4). 
Table 4. The number of forest fires and their area by forestry.

\begin{tabular}{|c|c|c|c|c|c|c|c|}
\hline \multirow[t]{2}{*}{ No. } & \multirow[t]{2}{*}{ Name of forestry } & \multicolumn{3}{|c|}{$\begin{array}{c}\text { Number of forest fires. pcs / } \\
\text { year }\end{array}$} & \multicolumn{3}{|c|}{ Area of forest fires. ha } \\
\hline & & 2017 & 2018 & 2019 & 2017 & 2018 & 2019 \\
\hline 1. & Arkharinskoye & 38 & 31 & 49 & 2074 & 72699 & 13077 \\
\hline 2. & Belogorskoye & 0 & 17 & 11 & 0 & 198872 & 5294 \\
\hline 3. & Blagoveshchenskoye & 28 & 36 & 21 & 967 & 7632 & 7631 \\
\hline 4. & Bureyskoye & 23 & 31 & 19 & 19353 & 44225 & 1269 \\
\hline 5. & Zavitinskoe & 12 & 30 & 20 & 2276 & 16638 & 4461 \\
\hline 6. & Zeyskoye & 61 & 50 & 75 & 117068 & 972748 & 21528 \\
\hline 7. & Magdagachinskoye & 37 & 51 & 35 & 13856 & 155804 & 57710 \\
\hline 8. & Mazanovskoye & 11 & 29 & 25 & 5655 & 345469 & 19732 \\
\hline 9. & Norskoye & 15 & 30 & 9 & 22114 & 133613 & 4821 \\
\hline 10. & Svobodnenskoye & 33 & 29 & 42 & 883 & 69121 & 31640 \\
\hline 11. & Tyndinskoye & 36 & 21 & 88 & 38202 & 72467 & 85264 \\
\hline 12. & Urushinskoye & 22 & 28 & 39 & 2928 & 8065 & 7982 \\
\hline 13. & Shimanovskoye & 6 & 50 & 22 & 2019 & 171208 & 11000 \\
\hline & Total: & 322 & 433 & 455 & 227395 & 2268561 & 271409 \\
\hline
\end{tabular}

There is no direct dependence of the number of forest fires in forestries on the length of mineralized belts per unit area (Fig. 2).

The largest number of fires on the territory of the state forest fund (SFF) was recorded in 2019. however. the largest area of fires was revealed in 2018.

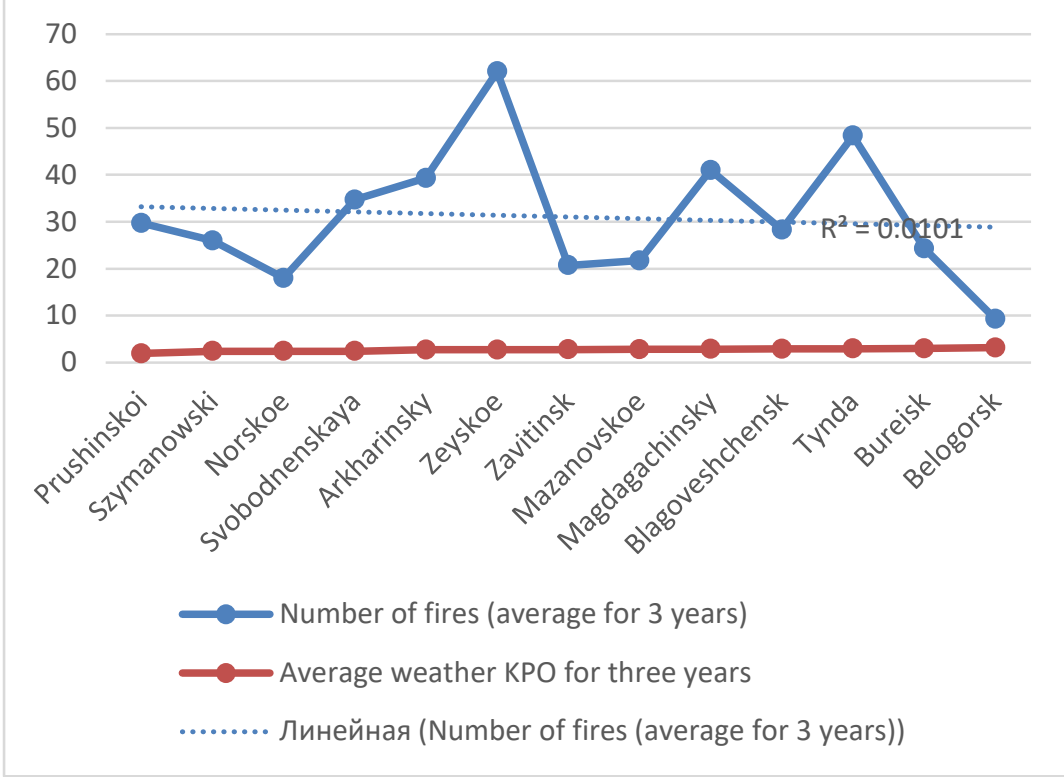

Fig. 2. The number of forest fires depending on the length of mineralized belts in the State Forest Fund of the Amur Region by forestries for 2017-2019.

The construction of a trend line and determination of the coefficient of accuracy of the approximation. based on the length of the mineralized belts and the number of forest fires. indicates the absence of relationships between these indicators.

As can be seen in Fig. 2. the largest number of forest fires in all analyzed time periods occurs in the Zeyskoye and Tyndinskoye forestries. The greatest length of fire-prevention mineralized belts per unit area (1 hectare) is recorded in the Blagoveshchenskoye forestry. 


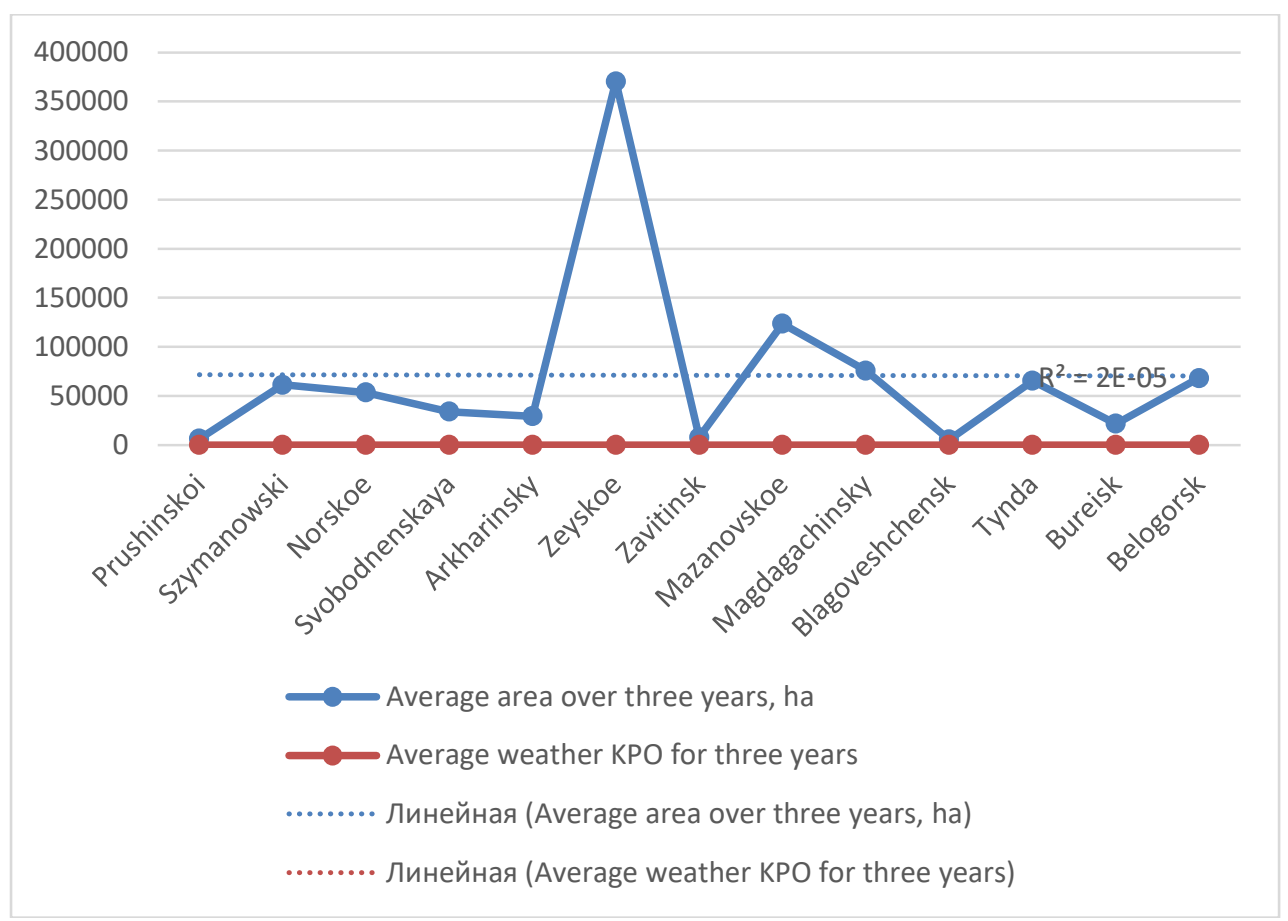

Fig. 3. Dependence of the area of forest fires on the length of mineralized belts per unit area of the State Forest Fund of the Amur Region by forestry for 2017-2019.

As can be seen from Fig.s 2 and 3. the dependence of the area of forest fires and their number on the length of the mineralized belts is not traced. The existing length of the mineralized belts practically does not affect the area and number of forest fires. It is possible to recognize the fact of ineffectiveness of the arrangement of mineralized belts to prevent the occurrence and spread of forest fires.

Table 5. The number of forest fires and the class of fire hazard by weather conditions in forestries.

\begin{tabular}{|l|l|c|c|c|c|c|c|}
\hline \multirow{2}{*}{ No. } & Name of forestry & \multicolumn{3}{c|}{$\begin{array}{c}\text { Number of forest fires. } \\
\text { pcs / year }\end{array}$} & \multicolumn{3}{c|}{$\begin{array}{c}\text { Average annual class of fire } \\
\text { hazard by weather } \\
\text { conditions }\end{array}$} \\
\cline { 3 - 9 } & & 2017 & 2018 & 2019 & 2017 & 2018 & 2019 \\
\hline 1. & Arkharinskoye & 38 & 31 & 49 & 2.9 & 3.0 & 2.6 \\
\hline 2. & Belogorskoye & 0 & 17 & 11 & 2.6 & 2.9 & 2.9 \\
\hline 3. & Blagoveshchenskoye & 28 & 36 & 21 & 2.4 & 3.3 & 2.4 \\
\hline 4. & Bureyskoye & 23 & 31 & 19 & 2.9 & 3.3 & 2.7 \\
\hline 5. & Zavitinskoe & 12 & 30 & 20 & 2.3 & 2.9 & 4.3 \\
\hline 6. & Zeyskoye & 61 & 50 & 75 & 1.9 & 3.4 & 2.9 \\
\hline 7. & Magdagachinskoye & 37 & 51 & 35 & 2.1 & 2.9 & 2.3 \\
\hline 8. & Mazanovskoye & 11 & 29 & 25 & 2.4 & 2.6 & 2.3 \\
\hline 9. & Norskoye & 15 & 30 & 9 & 1.9 & 2.1 & 1.7 \\
\hline 10. & Svobodnenskoye & 33 & 29 & 42 & 2.4 & 3.3 & 3.0 \\
\hline 11. & Tyndinskoye & 36 & 21 & 88 & 2.3 & 2.3 & 2.6 \\
\hline 12. & Urushinskoye & 22 & 28 & 39 & 2.6 & 2.9 & 3.3 \\
\hline 13. & Shimanovskoye & 6 & 50 & 22 & 2.4 & 3.1 & 2.9 \\
\hline & Total: & 322 & 433 & 455 & - & - & - \\
\hline
\end{tabular}


In connection with the above. we consider it expedient to identify the dependence of forest fires on the fire hazard class in terms of weather conditions.

The fire hazard class for weather conditions was determined as an arithmetic mean value for a fire hazardous season.

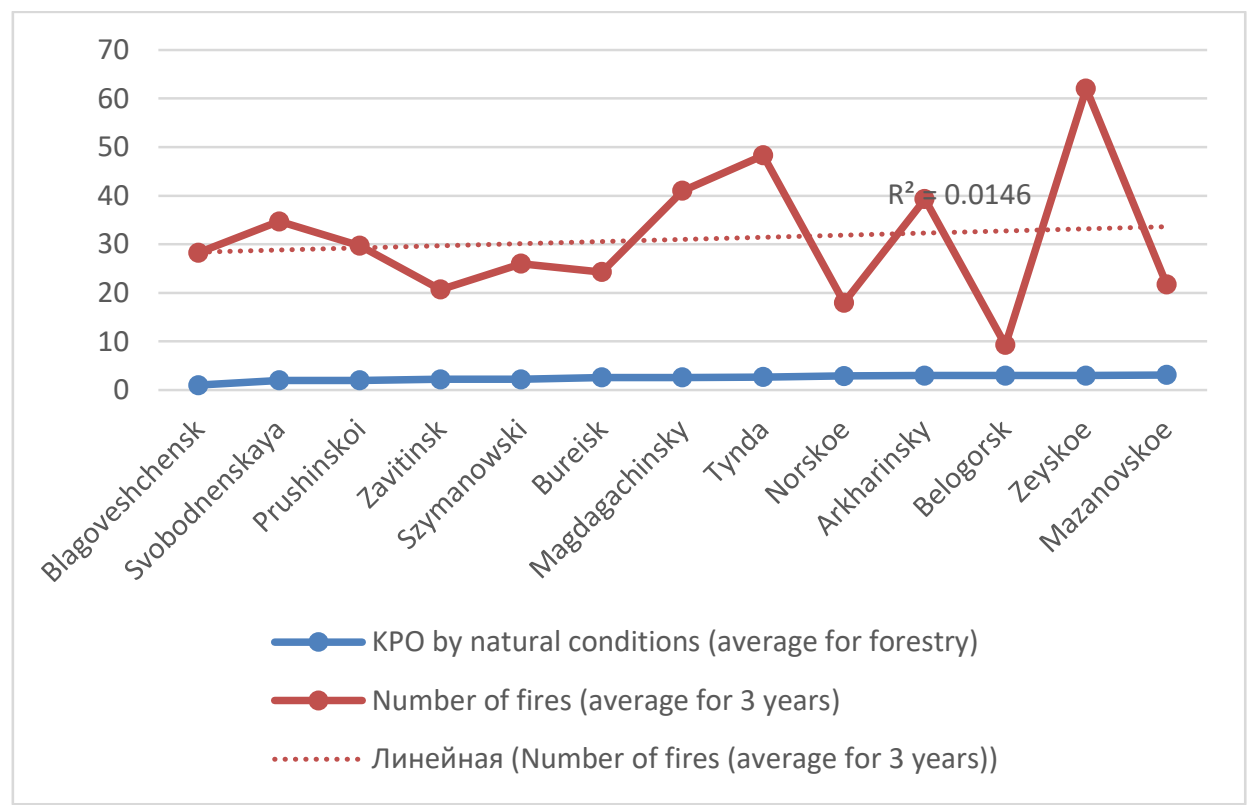

Fig. 4. Dependence of the number of fires on the fire hazard class by weather conditions in 2017 on the territory of the state forest fund of the Amur region.

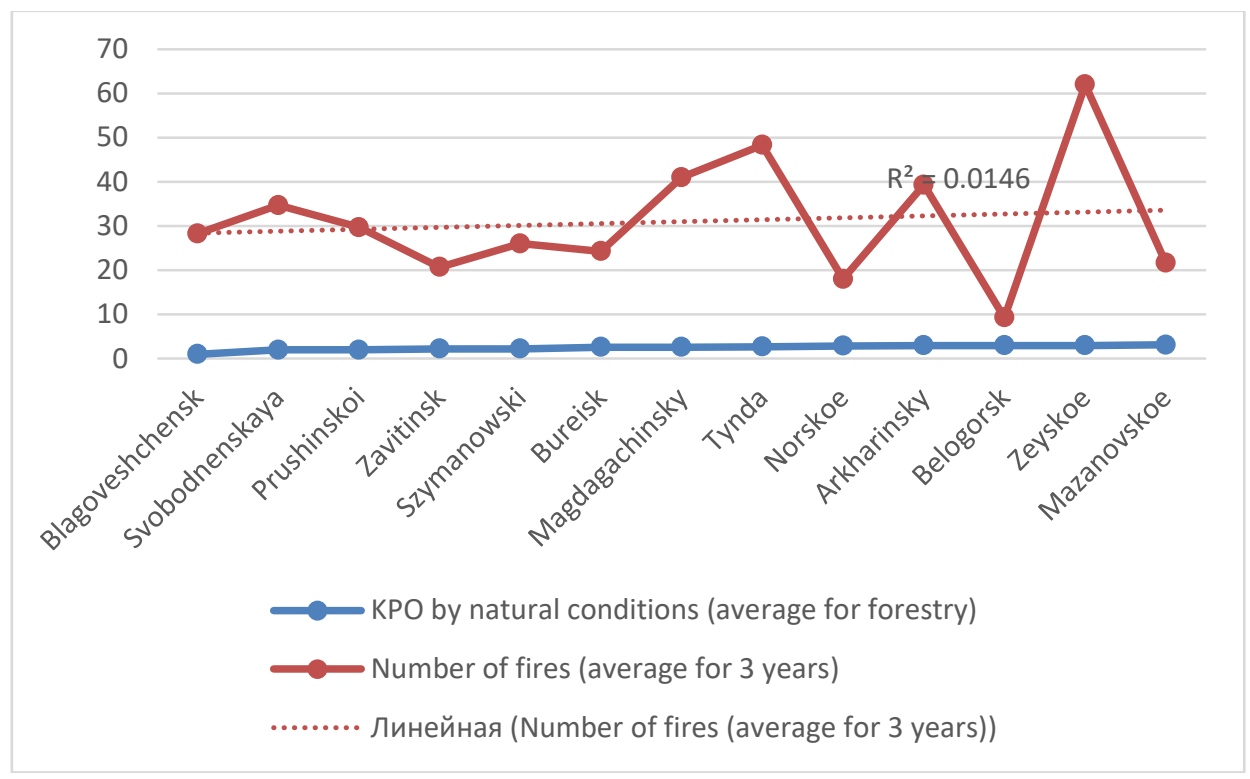

Fig. 5. Dependence of the number of fires on the fire hazard class by weather conditions in 2018 on the territory of the state forest fund of the Amur region. 
Fig.s 4. 5. clearly show the dependence of the number of forest fires on the fire hazard class for weather conditions. while the coefficient of approximation reliability (R2) varies from 0.848 to 0.9127 . these values suggest a high model adequacy.

As a result of data processing. three linear equations were obtained for the dependence of the number of forest fires on the fire hazard class according to weather conditions:

- for $2017 \mathrm{y}=0.533 \mathrm{x}+12.962$

- for $2018 \mathrm{y}=0.6758 \mathrm{x}+15.654$

- for $2019 \mathrm{y}=0.978 \mathrm{x}+12.385$.

An equation was derived mathematically. taking into account the data for the last three years. which makes it possible to determine the number of fires $(y)$ depending on the fire hazard class by weather conditions $(\mathrm{x})$.

$y=0.729 x+13.677$

With an increase in the amount of data processed using the model. the forecasting accuracy will increase.

4. Discussion

In the presented study. we analyzed the relationship between the number and area of forest fires on the territory of the Amur Region. depending on the area of forestries. the length of mineralized belts in each forestry. the length of mineralized belts per unit area of the forestry. natural fire hazard class. fire hazard class for weather conditions.

Based on the results of data analysis. the absence of dependence of the length of the mineralized belts on the area of the forestry was revealed. We believe that it is necessary for the constituent entities of the Russian Federation to develop clear instructions on justifying the placement of mineralized fire belts.

Also. no dependence was revealed between the number of forest fires and their area on the length of the mineralized belts across forestries. This fact indicates the lack of analysis in the distribution of the length of the mineralized belts across forestries. From our point of view. a controllable variable factor. such as the distribution of mineralized bands. should take into account statistical data on the number and areas of forest fires of previous years and increase in the territories of those forestries where there is a dynamics in the increase in the number and area of fires.

\section{Conclusions}

A stable relationship between the number of forest fires and the fire hazard class by weather conditions has been revealed. This dependence is presented in the form of a model that makes it possible to predict the number of forest fires both on the territory of the forest fund of the entire Amur Region. and for individual forestries.

The accumulation of statistical data and their analysis. using the model developed by us. will make it possible to make managerial decisions on the distribution of fire-fighting measures in forest districts and the concentration of forces and means of monitoring and fire extinguishing in forest districts.

\section{References}

1. D.R. Anto Evaluation of Meteorological Forest Fire Risk Indices and Projection of Fire Risk For German Federal States Master Thesis Warsaw University of Life Sciences (2011)

2. J. Bedia. S. Herrera. J.M. Gutiérrez. A. Benali. S. Brands. B. Mota. J.M. Moreno Global patterns in the sensitivity of burned area to fire-weather: Implications for 
climate change Agric. For. Meteorol, 214-215 369-379. (2015). https://doi.org/10.1016/j.agrformet.2015.09.002

3. El Bouhissi. M. . Bouidjra. S. and Benabdeli. K. GIS. Forest Fire Prevention and Risk Matrix in the National Forest of Khoudida. Sidi Bel Abbes. Algeria, Open Journal of Ecology 356-369 (2020) doi: 10.4236/oje.2020.106022.10..

4. F. Chen. S. Niu. X. Tong. J. Zhao. Y. Sun. T. He The impact of precipitation regimes on forest fires in Yunnan Province. Southwest China Sci. World J..(2014). Article 326782. 10.1155/2014/326782

5. M. Diakakis. G. Xanthopoulos. L. Gregos Analysis of forest fire fatalities in Greece: 1977-2013 Int. J. Wildland Fire, $25 \quad$ (7), 797-809 (2016). https://doi.org/10.1071/WF15198

6. M.A. Finney The challenge of quantitative risk analysis for wildland fire Forest Ecol. Manag, 211 (1), 97-108 (2005). 10.1016/j.foreco.2005.02.010 https://doi.org/

7. K. Lagouvardos. V. Kotroni. T.M. Giannaros. S. Dafis Meteorological conditions conducive to the rapid spread of the deadly wildfire in Eastern Attica. Greece Bull. the Am. Meteorol. Soc.. 100, 2137-2145, (2019). 10.1175/bams-d-18-0231.1

8. N. Read. T.J. Duff. P.G. Taylor A lightning-caused wildfire ignition forecasting model for operational use Agric. For. Meteorol, 253-254, 233-246 (2018). https://doi.org/10.1016/j.agrformet.2018.01.037

9. M. Rodrigues. J.C. González-Hidalgo. D. Peña-Angulo. A. Jiménez-Ruano Identifying wildfire-prone atmospheric circulation weather types on mainland Spain Agric. For. Meteorol.. 264 (j.agrformet.2018.10.005) (2019). pp. 92-103 https://doi.org/10.1016/

10. M. Rodrigues. R.M. Trigo. C. Vega-García. A. Cardil Identifying large fire weather typologies in the Iberian Peninsula Agric. For. Meteorol, 280 (2020). Article 107789. https://doi.org/10.1016/j.agrformet.2019.107789

11. J. San-Miguel-Ayanz. T. Durrant. R. Boca Moffat Forest fires in Europe Middle East and North Africa Publications Office of the European Union. Luxembourg (2018). https://doi.org/10.2760/663443 978-92-79-92831-4

12. R.L. Snyder. D. Spano. P. Duce. D. Baldocchi. L. Xu. K.T. Paw U A fuel dryness index for grassland fire-danger assessment Agric, Meteorol, 139 (1-2), 1-11 (2006). https://doi.org/10.1016/j.agrformet.2006.05.006

13. S.W. Taylor. M.E. Alexander Science. technology. and human factors in fire danger rating: the Canadian experience Int. J. Wildland Fire, 15, 121-135 (2006).

14. C. Wastl. C. Schunk. M. Lüpke. G. Cocca. M. Conedera. E. Valese. A. Menzel Largescale weather types. forest fire danger. and wildfire occurrence in the Alps Agric. Meteorol. 168, 15-25 (2013). https://doi.org/10.1016/j.agrformet.2012.08.011 